\title{
Internal integration as a pre-condition for external integration in global sourcing: A social capital perspective
}

\author{
Philipp Horn*, Paul Scheffler, Holger Schiele \\ University of Twente, School of Management and Governance, P.O. Box 217, NL-7500 AE Enschede, The Netherlands
}

\section{A R T I C L E I N F O}

\section{Article history:}

Received 10 December 2012

Accepted 25 March 2014

Available online 1 April 2014

Keywords:

Global sourcing

Integration

Social capital

\begin{abstract}
A B S T R A C T
The purpose of this study is to explore the link between integration and global sourcing success in international operations and by doing so, to clarify the ambiguous picture that prevails in the existing literature. Specifically, this quantitative study aims at identifying the role of the buying companies' internal and external integration with suppliers using a social capital lens. Data were collected from the central purchasing department of a multinational automotive OEM located in Germany. A sample of 82 purchasers was surveyed about their assessment of global sourcing projects, focusing on internal crossfunctional integration, external supplier integration and project success. The data were analyzed with structural equation modeling procedures, using SmartPLS. The findings indicate that internal integration is a precondition for external integration with suppliers, which accordingly has a strong positive influence on global sourcing success. Surprisingly, the direct relationship between internal and external integration was not significant, indicating a mediating role of social capital within this relationship. The theoretical originality lies in the use of the social capital theory and its three dimensions: cognitive, structural and relational capital for both internal and external integration, and in the connection between integration and global sourcing success. From a practical perspective, it can be recommended that managers distinguish between an internal and an external perspective. Internally, the focus should lie on the clear communication of common goals and norms, whereas externally, the definition of mutual contact points between organizations is of higher importance.
\end{abstract}

(c) 2014 Elsevier B.V. All rights reserved.

\section{Introduction}

Following the idea of lower factor costs in certain supply markets, there seems to be a strong consensus, in particular among practitioners, that international sourcing is either inevitable and/or beneficial for firms (Kotabe and Mudambi, 2009; Nassimbeni, 2006; Schiele et al., 2011a; Steinle and Schiele, 2008). Global sourcing has been called "an automatic expectation to respond to competition" (Carter et al., 2008, p. 225). However, previous findings concerning the results of global sourcing initiatives are somewhat contradictory; they show effects that range from negative to neutral (Kotabe and Omura, 1989; Murray et al., 1995; Schiele et al., 2011a) to 20\% savings (Petersen et al., 2000; Trent and Monczka, 2003b; Weber et al., 2010). Some scholars argue that global sourcing is primarily a means of generating short-term cost advantages on a unit price level (Petersen et al., 2000; Schiele et al., 2011a), omitting a longer-term total cost perspective (Holweg et al., 2011; Murray, 2001; Trent and Monczka, 2003b).

\footnotetext{
* Corresponding author.

E-mail address: p.horn@utwente.nl (P. Horn).
}

It has been argued that the success of global sourcing is based on the "worldwide integration of engineering, operations, and procurement centers within the upstream portion of a firm's supply chain" (Trent and Monczka, 2003b, p. 608). Thus, organizations face the challenge of integrating their internal functions with the entire supply chain (Golini and Kalchschmidt, 2011; Pagell, 2004). Apart from internal integration, recent research has investigated the link between external supplier integration and performance; the results suggest a positive effect of supplier integration on the buying firm's performance (Golini and Kalchschmidt, 2011; Lawson et al., 2008; Leana and Pil, 2006; Villena et al., 2011; Zhao et al., 2011) as well as a positive effect in the global sourcing context (Zhao et al., 2011).

Dyadic success factors for global sourcing, such as external integration between companies, have been widely researched, e.g., under a transaction cost economics view (Kotabe, 1994; Murray, 2001; Murray et al., 1995; Schneider et al., 2013) or the resourcebased view (Espino-Rodríguez and Padrón-Robaina, 2006). This research has employed case studies (Forza, 2009), surveys (Frohlich and Westbrook, 2001) and simulations. However, despite a call for research from various scholars (Petersen et al., 2000; Trent and Monczka, 2003b; Weber et al., 2010), the internal prerequisites for a firm's global sourcing success have been largely 
under-researched (Hartmann et al., 2008), although the importance of the integration of various functions within the firm for knowledge transfer and cooperation, e.g., for new product development (Kahn, 1996), make-or-buy decisions (Moses and Ahlstroem, 2009), and the general performance of the firm (Maltz and Kohli, 1996) has been shown.

Previous studies have also explored the interplay of internal and external integration in contexts such as product development (Koufteros et al., 2005) and general corporate performance outcomes (Droge et al., 2004). The results of these studies suggest that there may be a positive link between the two types of integration. However, it has not yet been shown how the joint effects of internal and external integration influence global sourcing success. Based on the prevailing literature, it cannot be stated a priori that internal and external integration also contribute to global sourcing success because global sourcing often incorporates special needs and particular firm characteristics (Trent and Monczka, 2003b, 2005).

This research paper aims to demonstrate that global sourcing is more than simply a set of tools designed to provide short-term cost savings. Specifically, the influence of intensified integration efforts is of interest. At the core of this research is the question of whether a high level of internal cross-functional integration contributes to a higher level of external integration (Koufteros et al., 2005) in a global sourcing context. Consequently, this work explores whether internal and external integration can serve as antecedents for successful global sourcing.

Because integration usually involves various elements of social interaction (Rabbiosi and Santangelo, 2013) and in line with prior research on integration in supply chain management, social capital theory has been chosen as the theoretical framework of the present research (Krause et al., 2007; Villena et al., 2011; Zhang and Huo, 2013). This leads, finally, to the main research question: Are internal integration of the functions within the buying firm and the accumulation of social capital prerequisites for external supplier integration, ultimately leading to increased global sourcing success?

The paper is structured as follows. After a brief literature review, our hypotheses regarding the relationship between social capital and internal and external integration, as well as the role of integration in the success of global sourcing, are presented. The chosen method of empirical analysis, which involves a sample of 82 global sourcing purchasing projects, is explained, and the results of our survey are discussed. The paper concludes with a discussion of the limitations of the research setting and some suggestions for further research.

\section{Theoretical considerations}

\subsection{Global sourcing and the internal - external integration link}

Since the 1990s, global business transactions have been growing considerably faster than domestic economies (Bowersox and Calantone, 1998), and multinational business has received increasing attention (Schiele et al., 2011a). The clear focus for firms on traditional western purchasing markets has been shown to lie in the cost-saving aspects of global sourcing (Alguire et al., 1994; Monczka and Giunipero, 1985; Spekman, 1991). While many terms, some of which have been precisely defined and some of which have been used interchangeably, have been used to describe global sourcing (Schiele et al., 2011a), the term "global sourcing" is herein employed as an umbrella term for cross-border sourcing aiming at cost savings.

As suggested in the literature, integrated global sourcing activities are usually more successful than sourcing activities that focus on arm's-length transactions (Horn et al., 2013; Pagell, 2004; Trent and Monczka, 2003a, b). As a consequence, integration has recently received increased attention in the context of operations management. In addition to pioneering publications such as that of Trent and Monczka (2003b), which elaborates on integrated global sourcing, a growing number of researchers have discussed the beneficial effects of internal integration (e.g. Foerstl et al., 2013; Pagell, 2004; Quintens et al., 2006; Trautmann et al., 2009) and external integration (e.g. Cousins and Menguc, 2006; Das et al., 2006; Fabbe-Costes and Jahre, 2007; Wiengarten et al., 2014) on operational performance. In contrast to publications that focus on internal cross-functional integration or on integration with external supply chain members, there has been a shift to research settings that examine both types of integration (e.g. Droge et al., 2004; Flynn et al., 2010; Kim, 2006; Koufteros et al., 2005; Wiengarten et al., 2014; Yang et al., 2013; Zhao et al., 2013). Nevertheless, despite the fact that the number of studies addressing internal and external integration has increased considerably, the proposed relationships among the effects and their moderators and mediators remain undefined, and a well-developed suitable theoretical framework is lacking.

In the reviewed literature, Schoenherr and Swink (2012) provide evidence concerning the moderating effect of internal integration on external integration, whereas Zhao et al. (2011) show a moderating role of supplier integration in customer integration. Gimenez and Ventura (2005) investigated Spanish companies and found evidence for the existence of a positive relationship between internal integration of the logistics function with the functions of other departments such as marketing and production and with external inter-organizational integration. However, Gimenez and Ventura (2005) assumed a bidirectional effect, meaning that internal integration facilitates external integration and vice versa. In contrast, Schoenherr and Swink (2012) emphasized the positive effect of internal integration on the relationship between external integration and delivery/flexibility performance. Their work broadly supports the findings of Droge et al. (2004), who analyzed a sample of first-tier suppliers from North American automotive OEMs. Their results indicate that “(...) the joint use of external and internal integration has synergistic effects on firm performance outcomes" (Droge et al., 2004, p. 570), implying that both types of integration deserve managerial attention. Still, Droge et al. (2004) conclude that the effects of interaction between internal and external integration has to a large extent been left unnoted, calling for further research. In a more recent study, Zhao et al. (2011) argued that external integration with market partners is positively influenced by internal functional integration and relationship commitment.

The results cited above indicate that internal integration is likely to exert an influence on external integration and on various measures of performance. However, the relationship between internal and external integration in purchasing and the mechanisms underlying this relationship are still ambiguous. In an attempt to close this gap, the present paper focuses on the link between the two types of integration.

\subsection{Social capital theory}

Within a supply chain management context, the importance of integration is emphasized in the literature (e.g. Fabbe-Costes and Jahre, 2007; Hamprecht et al., 2005; Pagell, 2004). The view of the positive effects of integration is not limited to an internal perspective (Pagell, 2004) but also covers external integration with suppliers (Krause et al., 2007; Lawson et al., 2008). Because integration refers to the process of interaction and collaboration to achieve mutually acceptable outcomes (Pagell, 2004), we posit a close linkage between social interaction and social capital and 
integration. The underlying idea is that buyer-supplier relationships represent multi-organization social processes in which the partners interact, exchange information, and form relationships based on interdependencies, exchanges, and mutual problemsolving (Hughes and Perrons, 2011). The positive conditions necessary for the exchange of such resources depend upon the development of social capital within these relationships (Hughes and Perrons, 2011).

The concept of social capital has gained increasing attention in the last decade (Krause et al., 2007; Lawson et al., 2008; Tsai and Ghoshal, 1998), and it has been investigated in the context of relationships between individuals and organizations (Ahuja, 2000; Tsai, 2000; Tsai and Ghoshal, 1998). Scholars within the supply chain management field have also used this theory as a "theoretical lens” (e.g. Krause et al., 2007; Lawson et al., 2008; Min et al., 2008). Despite these scientific efforts, our understanding of social capital and its role in a firm's value creation remains to a large extent unclear (Hughes and Perrons, 2011). According to Coleman's (1994) broadly shared view, social capital covers any aspect of social structure that facilitates the creation of value and supports the actions of individuals who belong to the social structure under investigation (Seibert et al., 2001). Based on this understanding, social capital can be defined as "the sum of the actual and potential resources embedded within, available through, and derived from the network of relationships possessed by an individual or social unit" (Nahapiet and Ghoshal, 1998, p. 243). Put another way, the guiding idea of social capital is the recognition of another's goodwill towards a certain entity as a valuable resource (Adler and Kwon, 2002).

Nahapiet and Ghoshal (1998) identify and delineate three dimensions of social capital, namely cognitive, structural and relational capital. The cognitive dimension includes shared interpretations; these are comparable to codes or paradigms that facilitate the understanding of the social system and its respective goals in terms of norms, values, attitudes, and beliefs (Tsai and Ghoshal, 1998; Uphoff and Wijayaratna, 2000). As emphasized by Inkpen and Tsang (2005), shared culture and congruent goals are substantive dimensions of cognitive capital (Villena et al., 2011). In this context, "shared culture refers to the degree to which norms of behavior govern relationships, whereas congruent goals represent the degree to which parties share a common understanding and approach to the achievement of common tasks and outcomes" (Villena et al., 2011, p. 562). Hence, it can be expected that the similarity of organizational cultures and also cultural differences on an individual level influence the corporate success of alliances (Parkhe, 1993). The reasons for this relationship are manifold. The reasons often mentioned are, among others, constraints on undesirable behavior in favor of collective interests (Coleman, 1994), improved harmony, and the reduction of opportunistic behavior (Ouchi, 1980).

The common understanding of structural social capital is that of a certain pattern of connections between entities, i.e., the connections an individual or an organization has and how these can be used (Burt, 1997; Villena et al., 2011). Hence, the presence or absence of network ties between participants is an important facet of this dimension (Nahapiet and Ghoshal, 1998). Depending on the structural configuration of the pattern, valuable resources that can lead to competitive advantages (Barney, 1991) can be accessed. For this reason, closure and density within the social structure are of primary interest because they facilitate the exchange of resources (Zaheer and Bell, 2005). In addition, various scholars have suggested that partnering entities can foster the exchange of reliable and diverse information (Guido et al., 2006; Koka and Prescott, 2002; Villena et al., 2011). As a result, particularly dense structures are assumed to be beneficial insofar as they permit reception of the right information at the right time
(Zaheer and Bell, 2005). Another potential benefit of dense relationship structures is that they make it possible to validate information and therefore increase its reliability as well as its diversity (Chen et al., 2009; Villena et al., 2011). For this reason, social capital theory argues that structural social capital is a valuable resource both for relationships within organizations and for relationships between them.

The relational dimension of social capital is ultimately based on the notion of Granovetter and Swedberg (1992) concerning embeddedness and refers to the relationships that people have developed with each other over time through interactions (Nahapiet and Ghoshal, 1998). Thus, relational social capital reflects the view that sources of competitive advantage can be based on relationships, extending the boundaries of the resourcebased view of the firm (Koufteros et al., 2010). In this regard, the basis for learning and know-how transfer within a relationship is based on mutual trust and interaction (Kale et al., 2000). Furthermore, because mutual trust and commitment play a major role in the relational component (e.g. Lee and Cavusgil, 2006), the relational dimension is delineated into trust and commitment. As a result of relational capital, the risk of opportunistic behavior as well as the possible leakage of critical knowledge is reduced (Kale et al., 2000). Hence, relational capital can improve corporate performance (Lawson et al., 2008).

It has been argued by scholars that there are certain relationships and dependencies between the social capital dimensions (e. g. Carey et al., 2011; Nahapiet and Ghoshal, 1998; Tsai and Ghoshal, 1998). To illustrate the associations between the social capital dimensions, Tsai and Ghoshal (1998) state that structural capital may stimulate the relational dimension of social capital. In this context, structural social capital, which is represented by social interaction ties, might induce trust and trustworthiness, leading to the accumulation of relational capital (Tsai and Ghoshal, 1998). This is reasonable assuming that trust between organizations or functions can be seen as an agglomeration of trust between individuals (Kale et al., 2000). Hence, this conclusion further supports the idea that individual social interaction ties (structural capital) are positively related to the emergence of relational capital. Similarly, the cognitive dimension of social capital can also be seen as an antecedent of relational capital. Prior research has indicated that trust, as an essential ingredient of relational capital, particularly emerges in relationships in which common goals and values (cognitive capital) exist between the parties (Carey et al., 2011). Thus, knowing about relevant norms and acting in accordance to them is likely to breed trust between partners (Carey et al., 2011; Nahapiet and Ghoshal, 1998).

Taking all aspects into consideration, we conclude that social capital and its respective dimensions (structural, relational, and cognitive) can be seen as beneficial for an organization's performance. We take this as the point of departure from which to investigate the applicability of the social capital theory in the domain of supply chain integration. Furthermore, in line with Murray (2001), we assume that companies that possess a higher level of external integration with suppliers in their global sourcing activities are particularly successful. Similarly, internal integration is expected to be indirectly beneficial for the performance of global sourcing organizations (Trautmann et al., 2009) due to the mediating role of social capital in this relationship. Thus, we extend the research on integration and firm performance (e.g. Schoenherr and Swink, 2012) by explicitly linking different forms of integration to global sourcing success.

\subsection{Hypotheses}

Internal integration, also often called cross-functional integration, refers to "the magnitude of interaction and communication, 
the level of information sharing, the degree of coordination, and the extent of joint involvement across functions" (Montoya-Weiss et al., 2001, p. 65). Cross-functional integration can be beneficial for communication, interaction, information sharing and coordination between functions, leading to a collaborative and interactive forum for different functions within a firm (Cheng et al., 2012; Hirunyawipada et al., 2010; Kahn, 1996; Montoya-Weiss et al., 2001). This collaborative environment is likely to be facilitated by the existence and accumulation of social capital (Leana and Pil, 2006; Sparrowe et al., 2001).

For a deeper understanding of the roles of individual social capital dimensions and in line with prior research, we argue that the development of relational capital within a firm is fostered by the accumulation of cognitive and structural capital (Carey et al., 2011; Tsai and Ghoshal, 1998). The rationale underlying this argument is that common values and a shared vision may encourage the development of trust, reducing tendencies to opportunistic behavior (Panayides and Venus Lun, 2009) and leading to the development of relational capital (Tsai and Ghoshal, 1998). Thus, the availability of common cognitive capital, that is, the ability of participants to make sense of their joint experiences, is seen as a precondition for the build-up of relational capital (Carey et al., 2011; Nahapiet and Ghoshal, 1998).

Similarly, the network of relationships, which is labeled structural capital, permits a flow of information and knowledge, paving the way for the benefits of relational capital (Carey et al., 2011). Previous research has shown that trust stems from social interaction ties, particularly those developed over time. This leads to the assumption that structural capital is beneficial for the accumulation of relational capital (Tsai and Ghoshal, 1998). To sum up, we assume that there is a positive relationship between both cognitive and structural capital and the development of relational capital. Relational capital, in turn, is likely to be positively related to successful internal integration. In this regard, Tsai and Ghoshal (1998, p. 467) state: "When two parties begin to trust each other, they become more willing to share their resources without worrying that they will be taken advantage of by the other party." Given the above-explained connection between relational capital and internal integration, we hypothesize that there is a positive relationship between relational capital and internal integration. As a result, hypotheses $\mathrm{H} 1$ and $\mathrm{H} 2$ have been formulated:

(H1a) The existence of internal cognitive capital is positively related to the accumulation of internal relational capital.

(H1b) The existence of internal structural capital is positively related to the accumulation of internal relational capital.

(H2) Internal relational capital is positively related to internal integration.

Once a cooperative environment has been developed within an organization, various beneficial effects can occur. Accordingly, it can be expected that if a firm's structures and processes are fragmented, the firm is less likely to possess the capabilities needed to resolve potential conflicts and actively support integration with external market partners (Zhao et al., 2011). Hence, it is not surprising that Gimenez and Ventura (2005) found a connection between a firm's ability to plan and work internally across functions and its planning and working performance with external supply chain partners. Because coordination of internal functions can also facilitate coordination with external market partners, some scholars argue that the establishment of a good relationship in terms of information sharing with the supplier and other functions can be seen as a precondition for successful supplier integration (e.g. Hughes and Perrons, 2011; Ragatz et al., 2002; Zhao et al., 2011). Therefore, we hypothesize a positive and direct relationship between internal cross-functional integration and external supplier integration, as reflected in H3:

(H3) Cross-functional integration is positively related to external supplier integration.

In addition to the direct relationship, we also expect the existence of an indirect path between cross-functional integration and supplier integration. Comparable to integration within the organization, social capital is likely to exert a significant influence. Beyond the purely functional perspective, social aspects of the buyer-supplier relationship have also begun to receive increasing attention from practitioners as well as from scholars (e.g. Adler and Kwon, 2002; Krause et al., 2007; Lawson et al., 2008).

In cross-functional integrated organizations, there is usually extensive cooperation and communication between departments (Rosenzweig et al., 2003; Sherman et al., 2000). In this collaborative environment, it is likely that the buying organization and the supplier can build up external social capital more easily than in situations in which the levels of internal integration are rather low (Caldwell and Hayes, 2007; Narasimhan and Kim, 2001). Often, internal integration incorporates the establishment of cross-functional teams that provide an appropriate means of creating structural ties between individuals and departments (Ellegaard and Koch, 2012; Schoenherr and Swink, 2012; Vickery et al., 2003). Put in another way, internal integration can support the structural connections between individuals or functions in an organization.

Similarly, it can be argued that the same capabilities that are necessary to create internal social and structural ties are likely to be beneficial to the accumulation of cognitive and structural capital with external partners because “(...) internal integration breaks down functional barriers and engenders cooperation in order to meet the requirements of customers (...)" (Flynn et al., 2010, p. 60 ). In this context, it can be argued that internally well-integrated organizations are experienced in managing social exchange processes, i.e., those organizations are able to use social exchange processes to encourage the communication of shared norms, goals, and values with other organizations (Thompson and Fine, 1999). As a consequence, $\mathrm{H} 4 \mathrm{a}$ has been formulated.

Successful internal integration could also facilitate the creation of structural capital with external partners. The underlying rationale of this relationship is that members of the supplier's organization can more easily find their respective counterparts in the buying organization when a dense network exists (Burt, 1997). Even if the right person is not contacted on the first attempt, it is likely that in a well-integrated organization the employees know each other's areas of expertise (Reagans and McEvily, 2003) and thus can assist the supplier in finding the suitable contact person. Therefore, it is hypothesized in H4b:

(H4a) Internal cross-functional integration is positively related to the accumulation of external cognitive capital with suppliers.

(H4b) Internal cross-functional integration is positively related to the accumulation of structural capital with suppliers.

There is evidence that social capital strengthens supplier relations (e.g. Gerlach, 1992; Helper, 1990; Smitka, 1991; Uzzi, 1997), and research has shown that investments in supplier development can lead to the build-up of social capital between the buyer and the supplier (Krause et al., 2007; Villena et al., 2011). The development of cognitive capital between the buyer and the supplier creates the potential for alignment of their business philosophies and fosters the negotiation of congruent goals (Villena et al., 2011). On the other hand, the existence of structural capital with the supplier makes it possible for the buying firm to 
benefit greatly from the supplier's extent and diversity of information, as well as for social ties to emerge (Leana and Pil, 2006). We further argue that personal relationships developed with the suppliers' organization, i.e., the external relational capital (trust and commitment) (Sambasivan et al., 2013; Villena et al., 2011), mediate the relationship between cognitive/structural capital and external integration (Carey et al., 2011; Tsai and Ghoshal, 1998; Vijayasarathy, 2010). In line with Tessarolo (2007, p. 73), external integration is defined as follows: "External integration is a strategic approach of the firm aimed at key boundary-spanning initiatives for fostering high-level coordination between a firm and its suppliers (...)". To conclude, we hypothesize that in addition to the direct link between internal cross-functional integration and external integration with suppliers there is also a path consisting of the three dimensions of social capital. As a result, $\mathrm{H} 5$ and $\mathrm{H} 6$ were developed:

(H5a) External cognitive capital with suppliers is positively related to the build-up of external relational capital with suppliers.

(H5b) External structural capital is positively related to the buildup of external relational capital with suppliers.

(H6) External relational capital with suppliers is positively related to external supplier integration.

In recent years, various scholars have investigated the link between external supplier integration and performance (e.g. Lawson et al., 2008; Leana and Pil, 2006). Most of this research suggests that supplier integration is beneficial to the buying firm's performance at the project or firm level (van der Vaart and van Donk, 2008). Furthermore, internal purchasing capabilities such as the alignment of purchasing strategy with other functional strategies have been shown to be beneficial for global sourcing success (Hartmann et al., 2008). This supports the view that global sourcing is "an advanced approach to sourcing and supply management that involves integrating and coordinating common materials, processes, designs, technologies and suppliers across worldwide buying, design and operating locations" (Trent and Monczka, 2005, p. 24). We also expect a positive relationship due to the assumption that the buying company can gain access to and leverage resources through collaborative relationships with its suppliers (Villena et al., 2011; Wagner, 2011), thereby benefiting from the existence of social capital between the organizations. This leads to H7, which is presented below. An overview of the proposed model is given in Fig. 1.

(H7) External supplier integration is positively related to global sourcing success.

\section{Research methodology}

\subsection{Data collection}

The aim of the paper is to investigate internal and external supply chain integration and its links to global sourcing performance. For the research at hand, a group of purchasers from the central purchasing department of a multinational automotive original equipment manufacturer (OEM) located in Germany were surveyed. By pursuing this research approach, we were able to benefit from the experience of purchasers who operate under comparable conditions in diverse industries.

A single-firm inductive research setting reduces confounding factors from industry and firm differences. The automotive industry was chosen for this study because it is of major importance in the world economy (Taylor and Taylor, 2008) and because it is of trend-anticipating character (Schiele et al., 2011a). The sampling method used in the study is purposive judgment sampling, a form of non-probability sampling, ensuring that the surveyed individuals were selected for conformity to a predetermined criterion, in this case that the purchaser is responsible for acquiring a part in a global sourcing context and that the purchaser is affiliated with the buying company (Blumberg et al., 2008). Using this method, a population of 186 purchasers involved in global sourcing activities within the focal company was identified. It was assumed that the relevant values, beliefs, and attitudes of this population are likely to be normally distributed and that representative inferences could thus be drawn from the data (Marshall, 1996). Because all the purchasers surveyed worked in the same division of one large OEM, it is reasonable to argue that all of them had passed through a comparable socialization process that allowed them to become acquainted with the companies' guidelines for doing business. This socialization process partly consisted of a three-month-long mandatory corporate qualification program for purchasers.

Purchasing projects were chosen at random from various countries and from a variety of industries. The purchasing department of the focal company is divided into five units, each specializing in one specific group of items (commodities). The survey was conducted among purchasers of electronics, interior equipment, exterior equipment, powertrain, and metal commodities. Each purchaser was asked in detail about his or her experiences with a supplier for one specific item that she or he sourced from a low-wage country. This ensured that relationships between the automotive OEM and many different suppliers with different industrial backgrounds were investigated; in other words, the research setting covers relationships between a large focal company and a diverse set of suppliers, generating increased credibility and generalizability of the study.

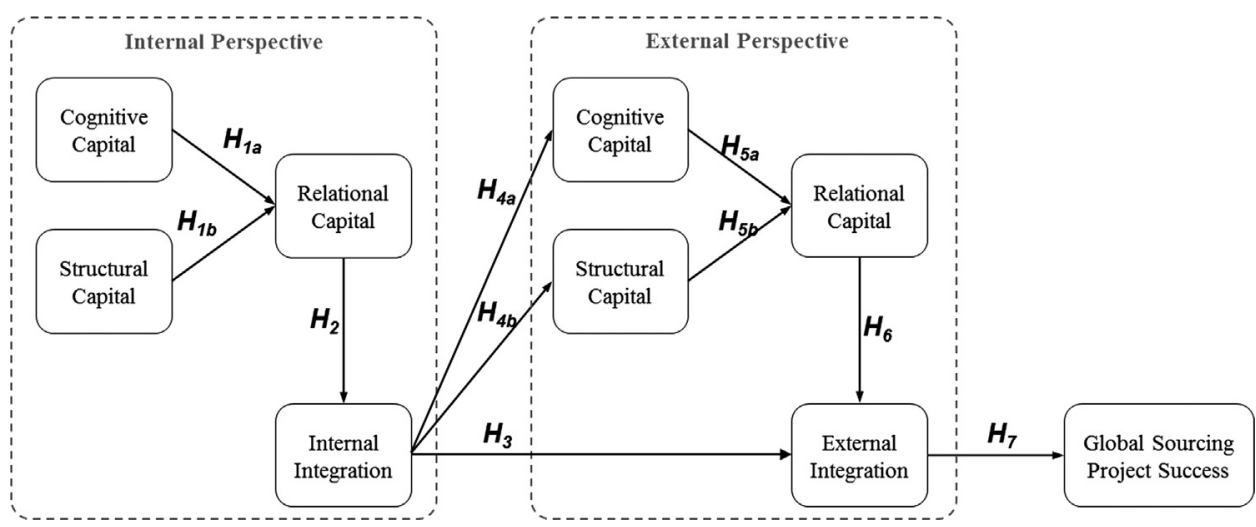

Fig. 1. Summary of the hypotheses. 
To maintain anonymity, two emails were sent to the purchasers. The first email contained information about a certain item purchased by that purchaser. The second email contained an automatically generated code number as well as a link to an online survey. If the system did not register an answer after 10 days, an automatically generated reminder email was sent to the purchaser. If there was no response within an additional ten days, follow-up calls were made to increase the response rate.

We achieved a final sample size of 82 , which represents a response rate of approximately $44.1 \%$. Response rates in the field have generally been low ( <30\%) (Forza, 2009; van der Vaart and van Donk, 2008). Higher response rates have been linked to close relationships of the researcher with the surveyed company (e.g. Vickery et al., 2003). The questionnaire was provided in German; to verify translation accuracy, the items on the questionnaire were translated into German and then translated back into English by a different researcher (Harkness et al., 2004). Pre-testing with selected purchasers (Forza, 2009) resulted in minor adjustments to the questionnaire.

\subsection{Measures}

Our measure generation process followed Churchill Jr (1979). As a first step, the domain of each construct was defined and the items to be included or excluded were stated. The second step consisted of a search for appropriate scales (Roth et al., 2007). Within the survey design, we employed proven measures for all latent variables, measuring the items by means of five-point Likert-type scales. Apart from the commitment measure, which together with the trust measure forms the relational capital construct, we used similar measures for all social capital constructs for internal and external social capital to maximize comparability. Cognitive capital was measured using the items designed by Mohr and Spekman (1994). Structural capital was measured according to Rindfleisch and Moorman (2001).

As introduced by Lee and Cavusgil (2006), relational capital included items concerning trust and commitment. For commitment on the supplier side, Kumar et al. (1994) measures were used; commitment on the internal side was measured using the items described by Rodríguez et al. (2007). Trust was measured taking items from (Kaufman et al., 2006). We used a general integration construct introduced by Monczka et al. (1998) for supplier integration and (Rodríguez et al., 2007) for internal integration.

According to van der Vaart and van Donk (2008, p. 51), performance was measured at the project level to "acquire reliable, less subjective, performance measures for the performance of a single relationship", following measures by Hoegl and Gemuenden (2001) in combination with Tatikonda and Montoya-Weiss (2001) as an alternative to overall and financial performance measures, which have been shown to be critical in many surveys (van der Vaart and van Donk, 2008). As control variables, we included length of relationship with the supplier for external social capital and external integration and job tenure for internal social capital and internal integration (Subramani, 2004).

\subsection{Analysis approach and psychometric properties}

The parameter estimates for the measurements and the structural model were obtained by partial least squares (PLS) path modeling with latent variables (Fornell and Cha, 1994; Ringle et al., 2005; Wold, 1982). The software package SmartPLS (Ringle et al., 2005) was used to carry out a confirmatory factor analysis (CFA) and to develop a structured equation model. SmartPLS uses a series of interdependent ordinary least squares (OLS) regressions to minimize residual variances (Chin, 1998) and has been shown to be suitable for estimating complex structural equation models and particularly for predicting dependent endogenous variables (Chin, 1998; Henseler et al., 2009). The PLS approach is particularly useful in cases involving small sample sizes and has been shown to result in robust findings (Chin, 1998), one of the core reasons we decided to apply this method. We used bootstrap re-sampling (Nevitt and Hancock, 2001) with replacement using 1000 rounds to assign measures of accuracy to our sample (Schiele et al., 2011b). Missing values were dealt with by mean replacement. The standardized path coefficients associated with our structural model are shown in Fig. 2.

The psychometric properties of the measurement instruments were measured using Smart PLS and SPSS and included reliability, convergent validity and discriminant validity (Burton et al., 2002; Tenenhaus et al., 2005). Because all of our constructs are reflective in nature (Edwards and Bagozzi, 2000), we assessed internal consistency and reliability using composite reliability (CR) (Fornell and Larcker, 1981; Wetzels et al., 2009) with average variance extracted (AVE) and with factor loadings (Edwards and Bagozzi, 2000; Hair et al., 2006). To assess the indicator reliability of the model, the individual item loadings with their respective constructs were analyzed as a first step. In all, seven items were removed due to insufficient factor loadings. In general, the items well exceeded the 0.7 threshold (Chin, 1998; Henseler et al., 2009). However, in line with Hulland (1999), we retained four items with factor loadings of $0.6 \times$.

With respect to convergent validity, each item strongly correlates with the construct to which it is related. Thus, convergent validity is satisfactory because all items load positively and with significant $t$-values on their respective constructs $(t>3.211)$. As shown in Table 1, all values exceed the recommended thresholds of 0.5 for AVE, 0.7 for CR (Edwards and Bagozzi, 2000; Fornell and Larcker, 1981; Nunnally and Bernstein, 1994) and 0.7 for Cronbach's alpha (Nunnally and Bernstein, 1994).

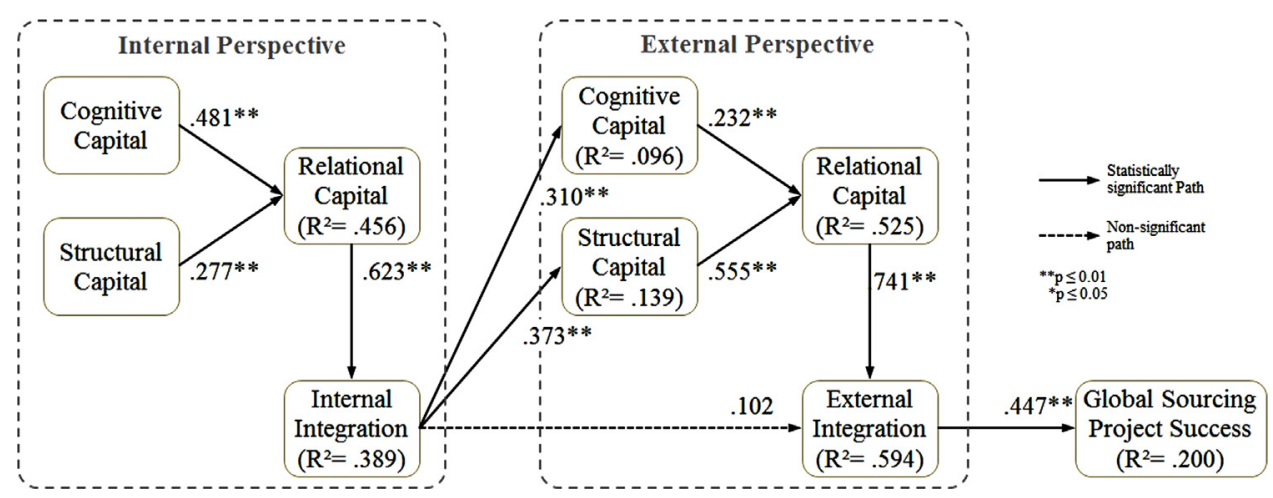

Fig. 2. PLS results of the structural model. 
Table 1

Convergent validity, reliability assessment and intercorrelations.

\begin{tabular}{|c|c|c|c|c|c|c|c|c|c|c|c|c|}
\hline Construct & $\mathrm{AVE}^{\mathrm{b}}$ & $\mathrm{CR}^{\mathrm{c}}$ & Cronb. $\alpha^{\mathrm{d}}$ & 1. Ext_Cog & 2. Ext_Integr & 3. Ext_Rel & 4. Ext_Str & 5. GS_ Suc & 6. Int_Cog & 7. Int_Integr & 8. Int_ Rel & 9. Int_Str \\
\hline 1. Ext_Cog & 0.58 & 0.85 & 0.76 & 0.76 & & & & & & & & \\
\hline 2. Ext_Integr & 0.74 & 0.90 & 0.82 & 0.60 & 0.86 & & & & & & & \\
\hline 3. Ext_Rel & 0.60 & 0.90 & 0.86 & 0.58 & 0.76 & 0.77 & & & & & & \\
\hline 4. Ext_Str & 0.66 & 0.85 & 0.74 & 0.63 & 0.70 & 0.70 & 0.81 & & & & & \\
\hline 5. GS_Suc & 0.60 & 0.92 & 0.91 & 0.34 & 0.45 & 0.36 & 0.30 & 0.78 & & & & \\
\hline 6. Int_Cog & 0.77 & 0.93 & 0.90 & 0.44 & 0.30 & 0.28 & 0.38 & 0.24 & 0.88 & & & \\
\hline 7. Int_Integr & 0.64 & 0.90 & 0.86 & 0.31 & 0.27 & 0.23 & 0.37 & -0.06 & 0.54 & 0.80 & & \\
\hline 8. Int_Rel & 0.64 & 0.91 & 0.88 & 0.49 & 0.23 & 0.34 & 0.39 & 0.07 & 0.64 & 0.62 & 0.80 & \\
\hline 9. Int_Str & 0.67 & 0.86 & 0.75 & 0.43 & 0.31 & 0.33 & 0.45 & 0.16 & 0.56 & 0.60 & 0.54 & 0.82 \\
\hline
\end{tabular}

${ }^{\mathrm{a} S q u a r e}$ root of AVE on the diagonal in bold.

${ }^{\mathrm{b}} \mathrm{AVE}=$ average variance extracted; $\mathrm{CR}=$ composite reliability; Cronb. $\alpha=$ Cronbach's $\alpha$.

${ }^{\mathrm{c}} \mathrm{CR}=$ composite reliability.

${ }^{\mathrm{d}}$ Cronb. $\alpha=$ Cronbach's $\alpha$.

To assess discriminant validity for the constructs, we used the Fornell-Larcker criterion (Fornell and Larcker, 1981), which suggests that the AVE of a latent variable should be higher than the squared correlations between that latent variable and other latent variables. In this way, latent variables explain the variance of their own indicators better than they explain the variance of other latent variables. Table 1 shows that the square roots of the AVE scores (presented in bold on the diagonal) are all larger than the cross-correlation scores. Because the data were collected by means of a questionnaire, Harman's one-factor test (Podsakoff and Organ, 1986) was used to check for common method variance (CMV), which could influence the modeled relationships. All items were loaded into a principal components factor analysis (PCA) with an unrotated solution. If one general factor were to account for most of the variance, CMV would pose a threat (Podsakoff and Organ, 1986). In our study, the first factor explained $32.53 \%$ of the variance. Therefore, CMV is not a concern.

\section{Findings}

Predictive validity within the model is medium to high. Approximately half of the variance in relational capital within the firm (45.6\%) and in relational capital with the supplier (52.5\%) can be explained by cognitive and structural capital. The existence of relational capital accounts for $38.9 \%$ of internal integration and for $59.4 \%$ of external integration, and $20 \%$ of global sourcing project success is explained by external integration with the supplier. All significant estimates have high statistical power with t-values exceeding 2.576 (Table 2).

Hypothesis 1 states that cognitive (1a) and structural (1b) capital positively influence relational capital. These hypotheses are strongly supported: both paths are positive and significant ( $\beta$ $0.481 ; t=5.105 / \beta$ 0.277; $t=2.774)$. In Hypothesis 2 , we stated that relational capital has a positive effect on supplier integration. Again, the effect was positive and statistically significant ( $\beta 0.623$; $t=10.434$ ). No empirical support was found for Hypothesis 3, which was based on the assumption that internal cross-functional integration would lead to external integration with the supplier. In the two-tailed test, the effect was small and not statistically significant ( $\beta$ 0.102; $t=1.599$ ). We furthermore hypothesized a positive relationship between internal cross-functional integration and cognitive capital with the suppliers (H4a) and between internal cross-functional integration and structural capital with the suppliers (H4b). We found support for Hypothesis $4 \mathrm{a}$ ( $\beta 0.310$; $t=3.341)$ as well as for Hypothesis $4 \mathrm{~b}(\beta 0.373 ; t=4.113)$. Similar to internal social capital, both cognitive and structural capital lead to relational capital with the supplier, as suggested in Hypotheses $5 \mathrm{a}$ $(\beta 0.232 ; t=2.593)$ and $5 \mathrm{~b}(\beta 0.555 ; t=7.003)$; both results are statistically significant and positive. We found strong support for Hypothesis 6, which states that relational capital with the suppliers leads to external integration with the suppliers ( $\beta$ 0.741; $t=15.656$ ). In addition, the data suggest that external integration is indeed positively related to global sourcing success, as stated in Hypothesis 7 ( $\beta 0.447 ; t=5.371$ ). Our two control variables, length of relationship with the supplier and tenure within the job, had no statistically relevant effect on our findings.

\section{Discussion}

The accumulation of cognitive and structural capital within an organization has been shown to facilitate the build-up of relational capital (Carey et al., 2011). Thus, the results of Tsai and Ghoshal (1998) as well as those of Carey et al. (2011) concerning the relationships between the social capital dimensions have been confirmed. Additionally, the study presents empirical evidence for the existence of a positive relationship between cross-functional integration and the build-up of social capital with suppliers. One insight gained from the results of the research at hand is that internal cross-functional integration does not directly lead to successful external integration with suppliers. This is somewhat surprising given that in a recent study (Zhao et al., 2011) found a significant relationship between internal integration and supplier integration. Our results instead indicate the need for an accumulation of social capital with the partnering organization (Villena et al., 2011) as a precondition for successful external integration. Thus, external integration with suppliers is a consequence of internal cross-functional integration and is influenced by the social capital between the two organizations. Hence, social capital plays a mediating role. This suggests that shared norms and values, in connection with social ties, pave the way for accessing resources associated with the relationships and that by doing so they facilitate external integration. Thus, the apparently simple link between internal integration and external integration is shown to be more complicated than expected.

The external social capital dimensions and their relationships to each other are congruent with the social capital relationships that exist within the company. Interestingly, the strength of the relationships differs. Whereas within the company the cognitive dimension of social capital exerts a stronger positive influence on the relational capital dimension, in the inter-organizational perspective this relationship is reversed; i.e., for the build-up of relational capital with suppliers, external structural capital is more beneficial than external cognitive capital. One possible interpretation of this finding is that within a single company cognitive capital in terms of shared values, attitudes, norms, etc. (Tsai and Ghoshal, 1998; Uphoff and Wijayaratna, 2000) is more important than the pattern of relationships between individuals or functions 
Table 2

Path coefficients.

\begin{tabular}{|c|c|c|}
\hline Path/hypothesis & Path coefficient & $t$-value \\
\hline Internal cognitive capital $\rightarrow$ internal relational capital (H1a) & 0.481 & $5.105^{* * *}$ \\
\hline Internal structural capital $\rightarrow$ internal relational capital (H1b) & 0.277 & $2.774^{* *}$ \\
\hline Internal relational capital $\rightarrow$ internal cross-functional integration $(\mathrm{H} 2)$ & 0.623 & $10.434^{* * *}$ \\
\hline Internal cross-functional integration $\rightarrow$ external integration with suppliers (H3) & 0.102 & 1.599 n.s. \\
\hline Internal cross-functional integration $\rightarrow$ cognitive capital with suppliers (H4a) & 0.310 & $3.341^{* * *}$ \\
\hline Internal cross-functional integration $\rightarrow$ structural capital with suppliers (H4b) & 0.373 & $4.113^{* * *}$ \\
\hline Cognitive capital with suppliers $\rightarrow$ relational capital with suppliers (H5a) & 0.232 & $2.593^{* *}$ \\
\hline Structural capital with suppliers $\rightarrow$ relational capital with suppliers (H5b) & 0.555 & $7.003^{* *}$ \\
\hline Relational capital with suppliers $\rightarrow$ external integration with suppliers (H6) & 0.741 & $15.656^{* *}$ \\
\hline External integration with suppliers $\rightarrow$ global sourcing success $(\mathrm{H} 7)$ & 0.447 & $5.371^{* * *}$ \\
\hline
\end{tabular}

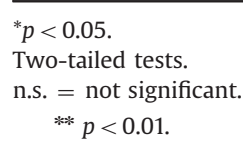

(Burt, 1997). In contrast, between organizations, the structural dimension of social capital seems to be of higher value than the cognitive one. A potential explanation of this finding could be that the membership of an individual in an organization is already equivalent to an initial endowment of structural capital in terms of the individual's ties to other organizational members. On the other hand, the existence of shared goals and visions (cognitive capital) might act as a framework for the alignment of actions and initiatives, facilitating exchange of and access to information that lies in relationships (relational capital). In contrast, in buyersupplier relationships, shared norms and values are indeed of interest but are not as important as the presence of certain contact points in the partnering company, which are the precondition for the exchange of resources such as information and knowledge. This interesting finding could potentially provide a new avenue for future research on social capital in buyer-supplier relationships. Furthermore, in line with scholars such as Lawson et al. (2008) and Carey et al. (2011), it was confirmed that external integration with suppliers has a significant positive impact on performance, which we operationalized as global sourcing success.

Taking all aspects of our findings into consideration, we have made a significant contribution to the operations management literature insofar as we investigated internal as well as external organizational integration under a social capital lens. In addition, integration was linked to global sourcing performance, and new avenues for future research were identified. Thus, the knowledge base of global sourcing has been extended.

In our data, we were not able to find evidence for the existence of "the dark side of buyer-supplier relationships", the idea that cognitive structural and relational capital can impede value creation in buyer-supplier relationships, as proposed by Villena et al. (2011). The main reasons posited for the presumed negative effects of too much social capital were the reduced ability to make effective decisions as well as increased opportunistic behavior by suppliers (Villena et al., 2011). On the contrary, the overall results of our study emphasize the high relevance of integration (internal and external) as well as social capital in buyer-supplier relationships.

To conclude, our study expands the existing body of knowledge regarding social capital theory with the following three points. First, social capital theory has been used to explain internal as well as external integration in the global sourcing context. Second, we showed that the strength of the relationships between the social capital dimensions within the buying company differs from the strength of the relationships between the buyer and the supplier. Third, our data showed that there is no direct and significant link between internal cross-functional integration and external integration with suppliers. Consequently, by investigating the internal perspective as well as the external perspective of social capital and integration, we have made valuable contributions to the field and have paved the way for further research in this domain, e.g., in the area dealing with the differing effect strengths of the social capital dimensions.

Considering that global sourcing by definition already involves various aspects of internal as well as external coordination and integration (Trent and Monczka, 2005), the existence of a positive relationship between external integration with suppliers and global sourcing success has been confirmed. In the light of this evidence, firms may wish to draw more attention to internal crossfunctional integration when facing problems in global sourcing. Some firms may lack the maturity needed for global sourcing not in terms of language or cultural skills, but due to deficits in internal integration. Knowledge of this positive relationship can support organizations in carefully developing their global sourcing and integration strategies to realize improvement opportunities and to shift toward globally integrated and coordinated sourcing strategies (Samli et al., 1998; Trent and Monczka, 2005). Consequently, integration is stimulated, potentially leading to improved global sourcing success.

\section{Implications for managers}

In the previous section, the theoretical implications of our findings were discussed. However, the results of the study also have implications for management practice. Because social capital accumulation and integration have been shown to be beneficial for global sourcing success, managers should facilitate integrative efforts (Pagell, 2004; Trent and Monczka, 2003b; Zhao et al., 2011). In contrast, when recommending procedures for increased global sourcing success, it is important to acknowledge that global competition forces companies to act in an efficient manner (Baily et al., 1995). For this reason, it is often necessary for companies to focus on activities that promise the most efficient use of the resources invested.

In this context, the data suggest that it is reasonable to distinguish between internal and external perspectives. To facilitate internal cross-functional integration, managers could focus on activities that support the accumulation of internal cognitive capital because this dimension has been shown to be fairly beneficial for successful internal integration. As a consequence, it is recommended that common goals and norms be clearly communicated, particularly within organizations, to increase the amount of cognitive capital.

Applying an external perspective, the data indicate that managerial activities should further aim at creating structural capital between organizations. While the results of our study suggest that it may indeed be beneficial to have similar norms, goals, and values (cognitive capital) between organizations, structural social 
capital was shown to be especially conducive to successful external integration. In accordance with these insights, clear paths should be defined among functions and individuals to create possible contact points between the members of the organizations and foster the build-up of structural capital. This approach might also support the emergence of relational capital and thus allow benefiting from the resources (e.g., knowledge and information) that lie within the relationships, potentially leading to increased organizational performance.

Taking these points into consideration, the results of our study suggest that social capital can be an efficient and effective tool that practitioners can use to support their integrative efforts and to increase corporate global sourcing success.

\section{Conclusion}

Based on the results of our survey, we conclude that internal cross-functional integration can be seen as a precondition for external integration with suppliers and global sourcing success. Surprisingly, the direct relationship between internal and external integration was not significant, indicating a mediating role of the three dimensions of social capital within this relationship. This finding emphasizes the importance of social capital within the firm as a facilitator for the development of social capital with external market partners such as suppliers. Put another way, internal integration is indeed beneficial for external integration under the condition of the presence of social capital.

Despite its contributions to the current body of knowledge, the present study has some limitations. First, only subjective measures were used to investigate the proposed model; this approach is, however, common in social sciences (Dess and Robinson Jr, 1984).
Second, a relatively small sample size $(N=82)$ was used to obtain our data, which were gathered through purposive judgment sampling within a large European automotive OEM. Despite the trendanticipating character of the automotive industry (Schiele et al., 2011a), this could limit the generalizability of the findings.

Despite these limitations, the results of our study are still meaningful because we carried out structural equation modeling in connection with PLS, which has minimal requirements regarding sample size, measurement scales, and residual distributions (Chin, 1998). Furthermore, van der Vaart and van Donk (2008) argue that high response rates, as were achieved in our case, should increase generalizability. Although our data were collected within only one German automotive OEM, industry bias has been alleviated to some extent by surveying the purchasers of items from a variety of industries such as plastics, metal and electronics in different countries.

In future research, this study could be used as a point of departure from which to elaborate further on the relationship between internal and external integration, which was not significant in our research setting. Furthermore, future studies could investigate whether the impact of the social capital dimensions and integration differs among industries. From a methodological perspective, highly credible results could be obtained from longitudinal research settings in combination with secondary data, as well as from in-depth case studies. In particular, studies involving larger samples and diverse buying organizations from different industries could provide an interesting avenue for future research to enrich the findings of this study.

\section{Appendix A. Measures}

See Table 3

Table 3

Measures.

\begin{tabular}{lll}
\hline Construct & Item & Loading \\
\hline $\begin{array}{c}\text { Internal Cognitive Capital } \\
\text { (Mohr and Spekman, 1994) }\end{array}$ & & \\
& Other departments participate in goal setting. & 0.913 \\
& Other departments participate in planning activities. & 0.900 \\
& We encourage other departments to come with suggestions for improvements. & 0.825 \\
& Other departments participate in forecasting activities. & 0.87
\end{tabular}

Internal Structural Capital

(Rindfleisch and Moorman, 2001)

Internal Relational Capital

Trust (Kaufman et al., 2006; Rodríguez et al., 2007)

When making decisions, other departments consider our business interest as well as their own. We trust that other departments keep our best interest in mind. Other departments are sincere and honest with us.

We believe the information, other departments provide.

Our employees share close social relationships with the employees from other departments. We like to spend time with employees from the other departments We spent a long time working together with other departments.

0.875

0.73

Commitment (Rodríguez et al., 2007)

My department is committed to the relationship with other departments.

We consider other departments as part of ours.

Internal Integration (Rodríguez et al., 2007)

Our departments help each other to accomplish their tasks in the most effective way.

The departments try to achieve goals jointly.

The departments share ideas, information and/ or resources.

The departments work together as a team.

The departments take the project's technical and operative decisions together.

0.798

0.816

0.874

0.797

0.68

0.803 
Table 3 (continued)

\begin{tabular}{|c|c|c|c|c|}
\hline Construct & Item & Loading & $\mathbf{C R}^{a}$ & $A V E^{b}$ \\
\hline & We ask the supplier to take part in our forecasting activities. & 0.792 & & \\
\hline & The supplier is collaborative. & 0.781 & & \\
\hline \multirow{4}{*}{$\begin{array}{l}\text { External Structural Capital } \\
\text { (Rindfleisch and Moorman, 2001) }\end{array}$} & & & 0.851 & 0.656 \\
\hline & Our employees share close social relationships with the employees from the supplier. & 0.882 & & \\
\hline & We like to spend time with employees from the supplier. & 0.766 & & \\
\hline & We feel indebted to the supplier for what it has done for us. & 0.778 & & \\
\hline \multirow{5}{*}{$\begin{array}{l}\text { External Relational Capital } \\
\text { Trust (Kaufman et al., 2006; Rodríguez } \\
\quad \text { et al., 2007) }\end{array}$} & & & 0.897 & 0.595 \\
\hline & When making decisions, the supplier considers our business interest as well as its own. & 0.827 & & \\
\hline & We trust that the supplier keeps our best interest in mind. & 0.888 & & \\
\hline & The supplier is sincere and honest with us. & 0.854 & & \\
\hline & We believe the information, the supplier provide. & 0.787 & & \\
\hline \multicolumn{5}{|l|}{ Commitment (Kumar et al., 1994) } \\
\hline & We want to remain a customer of the supplier. & 0.663 & & \\
\hline & $\begin{array}{l}\text { Our decision to remain customer of the supplier is also based on the attraction to the things that the } \\
\text { supplier represents as a company. }\end{array}$ & 0.627 & & \\
\hline \multirow{4}{*}{$\begin{array}{l}\text { External Integration (Monczka et al., } \\
\text { 1998) }\end{array}$} & & & 0.895 & 0.741 \\
\hline & The supplier makes an effort to help us during emergencies. & 0.84 & & \\
\hline & When an agreement is made, we can always rely on the supplier to fulfill requirements. & 0.851 & & \\
\hline & $\begin{array}{l}\text { Please indicate the overall degree of satisfaction concerning the collaboration with the supplier in } \\
\text { comparison to your most successful global sourcing project. }\end{array}$ & 0.89 & & \\
\hline \multicolumn{5}{|l|}{$\begin{array}{l}\text { Sourcing Success (Hoegl and } \\
\text { Gemuenden, 2001; }\end{array}$} \\
\hline \multirow[t]{9}{*}{ Tatikonda and Montoya-Weiss, 2001) } & & & 0.924 & 0.604 \\
\hline & From the departments perspective one could be satisfied with how the project progressed. & 0.846 & & \\
\hline & Overall, the project was done in a cost-efficient way. & 0.717 & & \\
\hline & From the companies perspective, the project goals were achieved. & 0.889 & & \\
\hline & The project was within schedule. & 0.702 & & \\
\hline & The original product performance objectives were met. & 0.802 & & \\
\hline & The original product unit-cost obejectives were met. & 0.748 & & \\
\hline & The original time to market objectives were met. & 0.754 & & \\
\hline & We received the planned and budgeded amount of goods. & 0.742 & & \\
\hline
\end{tabular}

\footnotetext{
${ }^{\mathrm{a}} \mathrm{CR}=$ composite reliability.

${ }^{\mathrm{b}} \mathrm{AVE}=$ average variance extracted.
}

\section{References}

Adler, P.S., Kwon, S.W., 2002. Social capital: prospects for a new concept. Acad. Manag. Rev. 27, 17-40.

Ahuja, G., 2000. Collaboration networks, structural holes, and innovation: a longitudinal study. Adm. Sci. Q. 45, 425-455.

Alguire, M., Frear, C., Metcalf, L., 1994. An examination of the determinants of global sourcing strategy. J. Bus. Ind. Market. 9, 62-74.

Baily, M.N., Gersbach, H., Scherer, F., Lichtenberg, F.R., 1995. Efficiency in manufacturing and the need for global competition. Brookings Papers on economic activity. Microeconomics 1995, 307-358.

Barney, J., 1991. Firm resources and sustained competitive advantage. J. Manag. 17, 99-120.

Blumberg, B., Cooper, D., Schindler, P., 2008. Business Research Methods: Second European edition. McGraw-Hill Higher Education, Maidenhead, UK.

Bowersox, D.J., Calantone, R.J., 1998. Global logistics. J. Int. Mark. 6, 83-93.

Burt, R.S., 1997. The contingent value of social capital. Adm. Sci. Q. 42, 339-365.

Burton, G., Carrol, G., Wall, S., 2002. Quantitative Methods for Business and Economics. Pearson Education, Harlow, UK.

Caldwell, C., Hayes, L.A., 2007. Leadership, trustworthiness, and the mediating lens. J. Manag. Dev. 26, 261-281.

Carey, S., Lawson, B., Krause, D.R., 2011. Social capital configuration, legal bonds and performance in buyer-supplier relationships. J. Oper. Manag. 29, 277-288.

Carter, J.R., Maltz, A., Yan, T., Maltz, E., 2008. How procurement managers view low cost countries and geographies. Int. J. Phys. Distrib. Logist. Manag. 38, 224-243.

Chen, H.H., Lee, P.Y., Lay, T.J., 2009. Drivers of dynamic learning and dynamic competitive capabilities in international strategic alliances. J. Bus. Res. 62, 1289-1295.

Cheng, T.C.E., Yip, F.K., Yeung, A.C.L., 2012. Supply riskmanagement via guanxi in the Chinese business context: the buyer'sperspective. Int. J. Prod. Econ. 139, 3-13.

Chin, W.W., 1998. The Partial Least Squares Approach for Structural Equation Modeling. Lawrence Erlbaum, Mahwah, NJ.

Churchill Jr, G.A., 1979. A paradigm for developing better measures of marketing constructs. J. Mark. Res. 16, 64-73.
Coleman, J.S., 1994. Foundations of Social Theory. Belknap Press, Cambridge, MA Cousins, P.D., Menguc, B., 2006. The implications of socialization and integration in supply chain management. J. Oper. Manag. 24, 604-620.

Das, A., Narasimhan, R., Talluri, S., 2006. Supplier integration - finding an optimal configuration. J. Oper. Manag. 24, 563-582.

Dess, G.G., Robinson Jr, R.B., 1984. Measuring organizational performance in the absence of objective measures: the case of the privately-held firm and conglomerate business unit. Strateg. Manag. J. 5, 265-273.

Droge, C., Jayaram, J., Vickery, S.K., 2004. The effects of internal versus external integration practices on time-based performance and overall firm performance. J. Oper. Manag. 22, 557-573.

Edwards, J.R., Bagozzi, R.P., 2000. On the nature and direction of relationships between constructs and measures. Psychol. Methods. 5, 155-174.

Ellegaard, C., Koch, C., 2012. The effects of low internal integration between purchasing and operations on suppliers' resource mobilization. J. Purch. Supply Manag. 18, 148-158.

Espino-Rodríguez, T., Padrón-Robaina, V., 2006. A review of outsourcing from the resource-based view of the firm. Int. J. Manag. Rev. 8, 49-70.

Fabbe-Costes, N., Jahre, M., 2007. Supply chain integration improves performance: the Emperor's new suit? Int. J. Phys. Distrib. Logist. Manag. 37, 835-855.

Flynn, B.B., Huo, B., Zhao, X., 2010. The impact of supply chain integration on performance: a contingency and configuration approach. J. Oper. Manag. 28, $58-71$.

Foerstl, K.D., Hartmann, E., Wynstra, F., Moser, R., 2013. Cross-functional integration and functional coordination in purchasing and supply management: antecedents and effects on purchasing and firm performance. Int. J. Oper. Prod. Manag. 33 (4-4).

Fornell, C., Cha, J., 1994. Partial least squares. In: Bagozzi, R.P. (Ed.), Advanced Methods of Marketing Research. Blackwell, Cambridge, MA, pp. 52-78.

Fornell, C., Larcker, D.F., 1981. Evaluating structural equation models with unobservable variables and measurement error. J. Mark. Res. 18, 39-50.

Forza, C., 2009. Surveys. In: Karlsson, C. (Ed.), Researching Operations Management. Routledge, New York and London, pp. 85-161. 
Frohlich, M., Westbrook, R., 2001. Arcs of integration: an international study of supply chain strategies. J. Oper. Manag. 19, 185-200.

Gerlach, M.L., 1992. Alliance Capitalism: The Social Organization of Japanese Business. University of California Press, Berkeley, CA.

Gimenez, C., Ventura, E., 2005. Logistics-production, logistics-marketing and external integration: their impact on performance. Int. J. Oper. Prod. Manag. $25,20-38$.

Golini, R., Kalchschmidt, M., 2011. Moderating the impact of global sourcing on inventories through supply chain management. Int. J. Prod. Econ. 133, 86-94.

Granovetter, M.S., Swedberg, R., 1992. The Sociology of Economic Life, CO. Westview press, Boulder.

Guido, C., Luca, I., Giuseppe, Z., 2006. A situationalist perspective to competency management. Hum. Resour. Manage. 45, 429-448.

Hair, J.F., Anderson, R.E., Tatham, R.L., Black, W.C., 2006. Multivariate Data Analysis, 6th ed.. Pearson, Upper Saddle River, NJ.

Hamprecht, J., Corsten, D., Noll, M., Meier, E., 2005. Controlling the sustainability of food supply chains. Supply Chain Manag.: Int. J. 10, 7-10.

Harkness, J., Pennell, B.E., Schoua, G., A., 2004. Survey questionnaire translation and assessment. In: Presser, S., Rothgeb, J.M., Couper, M.P. (Eds.), Methods for Testing and Evaluating Survey Questionnaires. John Wiley and Sons, New York, NY, pp. 453-473.

Hartmann, E., Bals, L., Kaiser, G., 2008. The impact of internal purchasing resources and capabilities on low-cost country sourcing. Zeitschrift für Betriebswirtschaft 78, 31-54.

Helper, S., 1990. Comparative supplier relations in the U.S. and Japanese auto industries: an exit/voice approach. Bus. Econ. Hist. 19, 153-162.

Henseler, J., Ringle, C.M., Sinkovics, R.R., 2009. The use of partial least squares path modeling in international marketing. Advances in International Marketing 20, 277-319.

Hirunyawipada, T., Beyerlein, M., Blankson, C., 2010. Cross-functional integration as a knowledge transformation mechanism: implications for new product development. Ind. Market. Manag. 39, 650-660.

Hoegl, M., Gemuenden, H., 2001. Teamwork quality and the success of innovative projects: a theoretical concept and empirical evidence. Organ. Sci. 12, 435-449.

Holweg, M., Reichhart, A., Hong, E., 2011. On risk and cost in global sourcing. Int. J. Prod. Econ. 131, 333-341.

Horn, P., Schiele, H., Werner, W., 2013. The ugly twins: failed low-wage-country sourcing projects and their expensive replacements. J. Purch. Supply Manag. 19, 27-38.

Hughes, M., Perrons, R.K., 2011. Shaping and re-shaping social capital in buyersupplier relationships. J. Bus. Res. 64, 164-171.

Hulland, J., 1999. Use of partial least squares (PLS) in strategic management research: a review of four recent studies. Strateg. Manag. J. 20, 195-204.

Inkpen, A.C., Tsang, E.W.K., 2005. Social capital, networks, and knowledge transfer. Acad. Manag. Rev. 30, 146-165.

Kahn, K.B., 1996. Interdepartmental integration: a definition with implications for product development performance. J. Prod. Innov. Manag. 13, 137-151.

Kale, P., Singh, H., Perlmutter, H., 2000. Learning and protection of proprietary assets in strategic alliances: building relational capital. Strateg. Manag. J. 21 (217-137).

Kaufman, P., Jayachandran, S., Rose, R.L., 2006. The role of relational embeddedness in retail buyers' selection of new products. J. Mark. Res. 43, 580-587.

Kim, S.W., 2006. The effect of supply chain integration on the alignment between corporate competitive capability and supply chain operational capability. Int. J. Oper. Prod. Manag. 26, 1084-1107.

Koka, B.R., Prescott, J.E., 2002. Strategic alliances as social capital: a multidimensional view. Strateg. Manag. J. 23, 795-816.

Kotabe, M., 1994. Global sourcing strategy: R\&D, manufacturing, \& marketing interfaces. J. Glob. Mark. 7 (157-157).

Kotabe, M., Mudambi, R., 2009. Global sourcing and value creation: opportunities and challenges. J. Int. Manag. 15, 121-125.

Kotabe, M., Omura, G., 1989. Sourcing strategies of European and Japanese multinationals: a comparison. J. Int. Bus. Stud. 20, 113-130.

Koufteros, X., Vonderembse, M., Jayaram, J., 2005. Internal and external integration for product development: the contingency effects of uncertainty, equivocality, and platform strategy. Decisi. Sci. 36, 97-133.

Koufteros, X.A., Rawski, G.E., Rupak, R., 2010. Organizational integration for product development: the effects on glitches, on-time execution of engineering change orders, and market success. Decis. Sci. 41, 49-80.

Krause, D.R., Handfield, R.B., Tyler, B.B., 2007. The relationships between supplier development, commitment, social capital accumulation and performance improvement. J. Oper. Manag. 25, 528-545.

Kumar, N., Scheer, L.K., Steenkamp, J.B.E.M., 1994. The effects of perceived interdependence on dealer attitudes. J. Mark. Res. 32, 348-356.

Lawson, B., Tyler, B.B., Cousins, P.D., 2008. Antecedents and consequences of social capital on buyer performance improvement. J. Oper. Manag. 26, 446-460.

Leana, C.R., Pil, F.K., 2006. Social capital and organizational performance: evidence from urban public schools. Organ. Sci. 17, 353-366.

Lee, Y., Cavusgil, S.T., 2006. Enhancing alliance performance: the effects of contractual-based versus relational-based governance. J. Bus. Res. 59, 896-905.

Maltz, E., Kohli, A., 1996. Market intelligence dissemination across functional boundaries. J. Mark. Res. 33, 47-61.

Marshall, M.N., 1996. Sampling for qualitative research. Family Pract. 13, 522-526

Min, S., Kim, S.K., Chen, H., 2008. Developing social identity and social capital for supply chain management. J. Bus. Logist. 29, 283-304.
Mohr, J., Spekman, R., 1994. Characteristics of partnership success: partnership attributes, communication behavior, and conflict resolution techniques. Strateg. Manag. J. 15, 135-152.

Monczka, R.M., Giunipero, L.C., 1985. International purchasing: characteristics and implementation. Int. Exec. 27, 2-9.

Monczka, R.M., Petersen, K.J., Handfield, R.B., Ragatz, G.L., 1998. Success factors in strategic supplier alliances: the buying company perspective. Decis. Sci. 29 553-577.

Montoya-Weiss, M.M., Massey, A.P., Song, X.M., 2001. Getting it together: temporal coordination and conflict management in global virtual teams. Acad. Manag. J 44, 1251-1262.

Moses, A., Ahlstroem, P., 2009. Nature of functional involvement in make or buy decision processes. Int. J. Oper. Prod. Manag. 29, 894-920.

Murray, J.Y., 2001. Strategic alliance-based global sourcing strategy for competitive advantage: a conceptual framework and research propositions. J. Int. Mark. 9, 30-58.

Murray, J.Y., Kotabe, M., Wildt, A.R., 1995. Strategic and financial performance implications of global sourcing strategy: a contingency analysis. J. Int. Bus. Stud. 26, 181-202.

Nahapiet, J., Ghoshal, S., 1998. Social capital, intellectual capital, and the organizational advantage. Acad. Manag. Rev. 23, 242-266.

Narasimhan, R., Kim, S.W., 2001. Information system utilization strategy for supply chain integration. J. Bus. Logist. 22, 51-75.

Nassimbeni, G., 2006. International sourcing: empirical evidence from a sample of Italian firms. Int. J. Prod. Econ. 103, 694-706.

Nevitt, J., Hancock, G.R., 2001. Performance of bootstrapping approaches to model test statistics and parameter standard error estimation in structural equation modeling. Struct. Equ. Model. 8, 353-377.

Nunnally, J.C., Bernstein, I.H., 1994. Psychometric Theory. McGraw, New York, NY. Ouchi, W.G., 1980. Markets, bureaucracies, and clans. Adm. Sci. Q. 25, 129-141.

Pagell, M., 2004. Understanding the factors that enable and inhibit the integration of operations, purchasing and logistics. J. Oper. Manag. 22, 459-487.

Panayides, P.M., Venus Lun, Y.H., 2009. The impact of trust on innovativeness and supply chain performance. Int. J. Prod. Econ. 122, 35-46.

Parkhe, A., 1993. Strategic alliance structuring: a game theoretic and transaction cost examination of interfirm cooperation. Acad. Manag. J. 36, 794-829.

Petersen, K.J., Prayer, D.J., Scannell, T.V., 2000. An empirical investigation of global sourcing strategy effectiveness. J. Supply Chain Manag. 36, 29-38.

Podsakoff, P.M., Organ, D.W., 1986. Self-reports in organizational research: problems and prospects. J. Manag. 12, 531-544.

Quintens, L., Pauwels, P., Matthyssens, P., 2006. Global purchasing strategy: conceptualization and measurement. Ind. Mark. Manag. 35, 881-891.

Rabbiosi, L., Santangelo, G.D., 2013. Parent company benefits from reverse knowledge transfer: the role of the liability of newness in MNEs. J. World Bus. 48, $160-170$.

Ragatz, G.L., Handfield, R.B., Petersen, K.J., 2002. Benefits associated with supplier integration into new product development under conditions of technology uncertainty. J. Bus. Res. 55, 389-400.

Reagans, R., McEvily, B., 2003. Network structure and knowledge transfer: the effects of cohesion and range. Adm. Sci. Q. 48, 240-267.

Rindfleisch, A., Moorman, C., 2001. The acquisition and utilization of information in new product alliances: a strength-of-ties perspective. J. Mark. 65, 1-18.

Ringle, C.M., Wende, S., Will, A., 2005. SmartPLS 2.0 (beta).

Rodríguez, N.G., Pérez, M.J.S., Gutiérrez, J.A.T., 2007. Interfunctional climate and a new product performance: dependence as a moderator. J. Bus. Ind. Mark. 22, 459-473.

Rosenzweig, E.D., Roth, A.V., Dean Jr, J.W., 2003. The influence of an integration strategy on competitive capabilities and business performance: an exploratory study of consumer products manufacturers. J. Oper. Manag. 21, 437-456.

Roth, A.V., Schroeder, R.G., Huang, X., 2007. Handbook of Metrics for Research in Operations Management: Multi-item Measurement Scales and Objective Items. Sage Publications, Inc, Thousand Oaks, CA.

Sambasivan, M., Siew-Phaik, L., Mohamed, Z.A., Leong, Y.C., 2013. Factors influencing strategic alliance outcomes in a manufacturing supply chain: role of alliance motives, interdependence, asset specificity and relational capital. Int. J. Prod. Econ. 141, 339-351.

Samli, A.C., Browning, J.M., Busbia, C., 1998. The status of global sourcing as a critical tool of strategic planning: opportunistic versus strategic dichotomy J. Bus. Res. 43, 177-187.

Schiele, H., Horn, P., Vos, B., 2011a. Estimating cost-saving potential from international sourcing and other sourcing levers: relative importance and trade-offs Int. J. Phys. Distrib. Logist. Manag. 41, 315-336.

Schiele, H., Veldman, J., Huettinger, L., 2011b. Supplier innovativeness and supplier pricing: the role of preferred customer status. Int. J. Innov. Manag. 15, 1-27.

Schneider, C.O., Bremen, P., Schonsleben, P., Alard, R., 2013. Transaction cost economics in globalsourcing: assessing regional differences and implications for performance. Int. J. Prod. Econ. 141, 243-254.

Schoenherr, T., Swink, M., 2012. Revisiting the arcs of integration: cross-validations and extensions. J. Oper. Manag. 30, 99-115.

Seibert, S.E., Kraimer, M.L., Liden, R.C., 2001. A social capital theory of career success. Acad. Manag. J. 44, 219-237.

Sherman, J.D., Souder, W.E., Jenssen, S.A., 2000. Differential effects of the primary forms of cross functional integration on product development cycle time. J. Prod. Innov. Manag. 17, 257-267.

Smitka, M., 1991. Competitive Ties: Subcontracting in the Japanese Automotive Industry. Columbia University Press, New York, NY. 
Sparrowe, R.T., Liden, R.C., Wayne, S.J., Kraimer, M.L., 2001. Social networks and the performance of individuals and groups. Acad. Manag. J. 44, 316-325.

Spekman, R., 1991. U.S. buyers' relationships with Pacific Rim sellers. Int. J. Purch. Mater. Manag. 27, 1-10.

Steinle, C., Schiele, H., 2008. Limits to global sourcing? Strategic consequences of dependency on international suppliers: cluster theory, resource-based view and case studies. J. Purch.Supply Manag. 14, 3-14.

Subramani, M., 2004. How do suppliers benefit from information technology use in supply chain relationships? MIS Q. 28, 45-73.

Tatikonda, M.V., Montoya-Weiss, M.M., 2001. Integrating operations and marketing perspectives of product innovation: the influence of organizational process factors and capabilities on development performance. Manage. Sci. 47, 151-172.

Taylor, M., Taylor, A., 2008. Operations management research in the automotive sector. Int. J. Oper. Prod. Manag. 28, 480-489.

Tenenhaus, M., Vinzi, V.E., Chatelin, Y.M., Lauro, C., 2005. PLS path modeling. Comput. Stat. Data. Anal. 48, 159-205.

Tessarolo, P., 2007. Is integration enough for fast product development?: an empirical investigation of the contextual effects of product vision. J. Prod. Innov. Manag. 24, 69-82.

Thompson, L., Fine, G.A., 1999. Socially shared cognition, affect, and behavior: review and integration. Personality and Social Psychology Review 3, 278-302.

Trautmann, G., Turkulainen, V., Hartmann, E., Bals, L., 2009. Integration in the globa sourcing organization - An information processing perspective. J. Supply Chain Manag. 45, 57-74.

Trent, R.J., Monczka, R.M., 2003a. International purchasing and global sourcing what are the differences? J. Supply Chain Manag. 39, 26-36.

Trent, R.J., Monczka, R.M., 2003b. Understanding integrated global sourcing. Int. J. Phys. Distrib. Logist. Manag. 33, 607-629.

Trent, R.J., Monczka, R.M., 2005. Achieving excellence in global sourcing. Sloan. Manage. Rev. 47, 24-32.

Tsai, W., 2000. The formation of intraorganizational linkages. Strat. Manag. J. 21, 925-939.

Tsai, W., Ghoshal, S., 1998. Social capital and value creation: the role of intrafirm networks. Acad. Manag. J. 41, 464-476.

Uphoff, N., Wijayaratna, C., 2000. Demonstrated benefits from social capital: the productivity of farmer organizations in Gal Oya, Sri Lanka. World Dev. 28, 1875-1890.
Uzzi, B., 1997. Social structure and competition in interfirm networks: the paradox of embeddedness. Adm. Sci. Q. 42, 35-67.

van der Vaart, T., van Donk, D.P., 2008. A critical review of survey-based research in supply chain integration. Int. J. Prod. Econ. 111, 42-55.

Vickery, S.K., Jayaram, J., Droge, C., Calantone, R.J., 2003. The effects of an integrative supply chain strategy on customer service and financial performance: an analysis of direct versus indirect relationships. J. Oper. Manag. 21, 523-539.

Vijayasarathy, L.R., 2010. Supply integration: an investigation of its multidimensionality and relational antecedents. Int. J. Prod. Econ. 124, 489-505.

Villena, V.H., Revilla, E., Choi, T.Y., 2011. The dark side of buyer-supplier relationships: a social capital perspective. J. Oper. Manag. 29, 561-576.

Wagner, S.M., 2011. Supplier development and the relationship life-cycle. Int. J. Prod. Econ. 129, 277-283.

Weber, M., Hiete, M., Lauer, L., Rentz, O., 2010. Low cost country sourcing and its effects on the total cost of ownership structure for a medical devices manufacturer. J. Purch.Supply Manag. 16, 4-16.

Wetzels, M., Odekerken-Schroder, G., Van Oppen, C., 2009. Using PLS path modeling for assessing hierarchical construct models: guidelines and empirical illustration. MIS Q. 33, 177-195.

Wiengarten, F., Pagell, M., Ahmed, M.U., Gimenez, C., 2014. Do a country's logistical capabilities moderate the external integration performance relationship? J. Oper. Manag. 32, 51-63.

Wold, H., 1982. Soft modeling: the basic design and some extensions. Syst. Under Indirect Obs. 2, 589-591.

Yang, J., Rui, M., Rauniar, R., Ikem, F.M., Xie, H., 2013. Unravelling the link between knowledge management and supply chain integration: an empirical study. Int. J. Logist. Res. Appl., 1-12.

Zaheer, A., Bell, G.G., 2005. Benefiting from network position: firm capabilities, structural holes, and performance. Strateg. Manag. J. 26, 809-825.

Zhang, M., Huo, B., 2013. The impact of dependence and trust on supply chain integration. Int. J. Phys. Distrib. Logist. Manag. 43, 544-563.

Zhao, L., Huo, B., Sun, L., Zhao, X., 2013. The impact of supply chain risk on supply chain integration and company performance: a global investigation. Supply Chain Manag. Int. J. 18, 115-131.

Zhao, X., Huo, B., Selen, W., Yeung, J.H.Y., 2011. The impact of internal integration and relationship commitment on external integration. J. Oper. Manag. 29, 17-32. 